\title{
屋久島河川水にあらわれる同位体高度効果と流出特性
}

\author{
山中 勝 ${ }^{* 1} \cdot$ 奥村 維男 ${ }^{* 2} \cdot$ 中野 孝教 ${ }^{* 3}$

\begin{abstract}
Isotopic altitude effect and discharge characteristics of river water in Yakushima Island, southwestern J apan
\end{abstract}

\author{
M asaru YAM ANAKA *1, M asao OKUM URA *2 and Takanori NAKANO *3
}

\begin{abstract}
Isotopic compositions were analyzed to grasp the altitude effect observed in and the discharge characteristics of river water in Yakushima Island, southwestern Japan. The isotopic characteristics of the river water are similar to those of precipitation in summer; a regression line for the river water is $\delta D=7.68 \delta^{18} \mathrm{O}+$ 10.06 and $d$ values are in a range of $6.5 \sim 16.1 \%$. M oreover, the altitude effects are $-0.17 \%$ / $100 \mathrm{~m}$ for $\delta{ }^{18} \mathrm{O}$ and-1.3\% / $100 \mathrm{~m}$ for $\delta \mathrm{D}$ irrespective of river drainage size. These altitude effects are well concordant with the values in the previous report in Japan, strongly indicating that the river water in Yakushima Island is scarcely affected by the processes of evaporation and mixing with groundwater having long residence time. This idea is not contradict with verifications using mass ratio of potential evapotranspiration in precipitation as an index. Such discharge characteristics of the river might be attributed to hydrological setting of Yakushima Island, i.e., lower permeability of granite and high amounts of precipitation up to $10,000 \mathrm{~mm} / \mathrm{yr}$ in the mountainous area. Some river water samples in central-northern and western parts of the Island have apparently light isotopic compositions against the average altitudes of drainage basin. Considering landforms of Yakushima Island and meteoric conditions, such isotopic data would be caused by rain shadow effect in which vapor mass as a source of these river water samples has been brought across a ridge by seasonal southern wind.
\end{abstract}

Key words: Yakushima Island, River water, Altitude effect, Stable isotopic composition キーワード：屋久島, 河川水, 高度効果, 安定同位体組成

$$
\text { I.はじめに }
$$

標高差のある流域において降水の水素・酸素同 位体組成は，高度効果による同位体分別の影響 を受けることが知られている(例えば Clark and Fritz, 1997; M azor，1997)。これによる同位体的特
徵は, 降水を供給源とする河川水や浅層地下水の 流動・流出プロセスを理解する上で有益な情報を 提供するものであり，この特徵を活用した水文 学的研究は国内外を問わず数多く行われている (Scholl et al., 1996 ; Yasuhara et al., 1997 ; 浅 井 ほか，2001)。一般に降水の高度効果は流域条件

* 1 日本大学文理学部地球システム科学科 Department of Geosystem Sciences, College of Humanities and Sciences, Nihon University

* 2 石油天然ガス・金属鉱物資源機構 Japan Oil, Gas and M etals National Corporation (JOGM EC)

* 3 総合地球環境学研究所 Research Institute for Humanity and Nature (RIHN) 
により変動することから，このような研究を行う ためには調査流域における降水の同位体組成の把 握が必要となる。しかしながら，同位体測定のた めに複数の地点で継続的な降水採取を行うことは 容易でなく，特に高い標高地域での試料採取は困 難をともなう。実際に, 標高 1,000 m 以上の地点 におけるデータを含む継続的な降水の同位体組成 の報告は，国内において風早·安原 (1994)，浅井 ほか (2001)，中村ほか (2002) などに限られる。

降水か地表面下に浸透し, 弚の後河川水として 地表に流出するまで同位体組成が変化しなけれ ば , 河川水の同位体組成は浸透した降水の值を反 映すると考えられる。この考えのもと，いくつか の研究では, 河川水を降水の代替物として关の高 度効果か論じられている (早稲田・中井, 1983 ; 水谷·佐竹, 1997 ; 宮下, 2001 ; 稲村·安原, 2003 ; 蔞崎ほか , 2003)。しかし, ,ほとんどの場合 には, 河川水は弚の流域特性に応じて, 蒸発によ る濃縮や, 異なる季節の降雨を供給源とした比較 的長い滞留時間を持つ地下水の混入といったプロ セスの影響を受ける。この結果, 光の同位体組成 は流域内の降水の高度効果に加え，流域の流出特 性を反映したものとなる。したがって，両者の影 響を分離できれば，降水からもたらされる高度効 果のみならず，流域で河川水が受けた蒸発率など 流出特性に関する情報が得られると考えられる (風早, 1997)。

東シナ海に位置する屋久島は $1,800 \mathrm{~m}$ 級の山々 が光びえる島嶼である。この大部分は花崗岩から なり，山体における透水性は低い。屋久島にはこ れに加えて「一月に 35 日雨か降る」と形容される ほど多くの雨が降る。特に山岳部における年間降 水量は，10,000 mm を超えるとの報告もある (日 下田, 2002)。二れら屋久島特有の自然条件は, 湧 水・沢水を含む河川水から同位体組成の高度効果 を把握する上で, 以下のような理想的水文環境を 提供している。(1) 屋久島では一般的な火山体と は異なり山岳部を含めた島の至る所に小規模な湧 水・沢水が存在しているため, 樣々な標高で水試 料の採水が可能である。(2) 屋久島の降水量は極
めて多いことから，小規模流域の湧水・沢水は降 水の同位体組成を堅持しながら，比較的短い期間 で湧出しているものと予想される。

以上の観点から, 本研究は小規模な流域におけ る湧水・沢水において产の同位体高度効果を検証 し，より大きな流域に対して適応を試みた。な お，屋久島の河川水水質についてはこれまでいく つかの報告が行われていることから (島野, 1999; Nakano et al., 2001 ; 海老瀬・永淵， 2002 ; 永淵ほ か, 2002 ; 林ほか, 2003 ; 山中・中野, 2004 ; 山 中ほか, 2005), 本研究では水質組成については取 り上げない。

\section{II. 対象地域概要}

対象地域である屋久島は, 九州最南端の佐多岬 の南南西約 $70 \mathrm{~km}$ の海上にある周囲 $132 \mathrm{~km}$, 面積 約 $500 \mathrm{~km}^{2}$ の円形をなす島である。島内には九州 最高峰である宮之浦岳 (標高 1,935 m) をはじめ とする 1,800 m 級の山々が光びえている (Fig. 1)。

屋久島の地質は古第三系の海底地すべり堆積物 からなる熊毛層群, 弚れを貫入する花崗岩からな る。島内の熊毛層群は北西部を除く海岸部に分布 しており, 屋久島花崗岩による接触変成を受けて ホルンフェルス化している (Fig. 2 ; 岩松・小川 内 ,1984)。島内の地形は一般に標高 $1,000 \sim 1,500$ $\mathrm{m}$ までは急激に高度を増すが, 弚れ以上では比較 的なだらかな起伏を持っている。平坦面は島南西 部の標高 $200 \mathrm{~m}$ 以下に多少存在するのみで, 扇状 地, 段丘, 沖積平野の発達は貧弱である。また, 島の植生は多彩であり, 海岸部には八イビスカス などの亜熱帯植物, 標高 $100 〜 800 \mathrm{~m}$ にはタブノ キなどの照葉樹，800〜1,600 mにはヤクスギな ど針葉樹，1,700 $\mathrm{m}$ 以上にはヤクザサなどの植物 が順に自生する。また山頂部では花崗岩が露出し ている。

山岳島である屋久島の気候は午の標高に応じた 大きな変化を示す。島北東海岸部の標高 $36 \mathrm{~m}$ に ある小瀬田気象観測所の年平均気温は $19.2^{\circ} \mathrm{C}$, 最 も寒い 1 月の平均気温でも $11.4^{\circ} \mathrm{C}$ と高い。一方で 


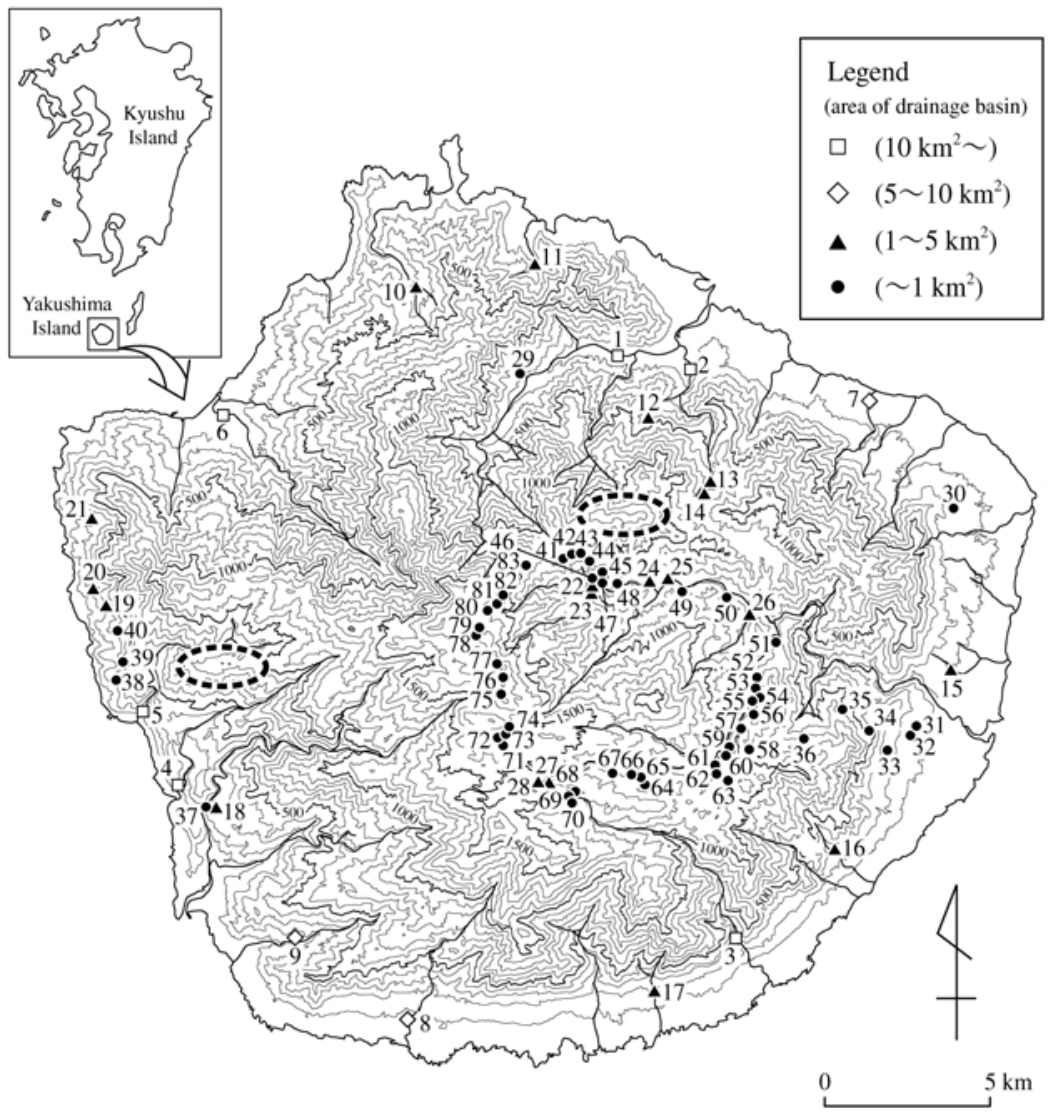

Fig. 1 Location of Yakushima Island and sampling points of river water.

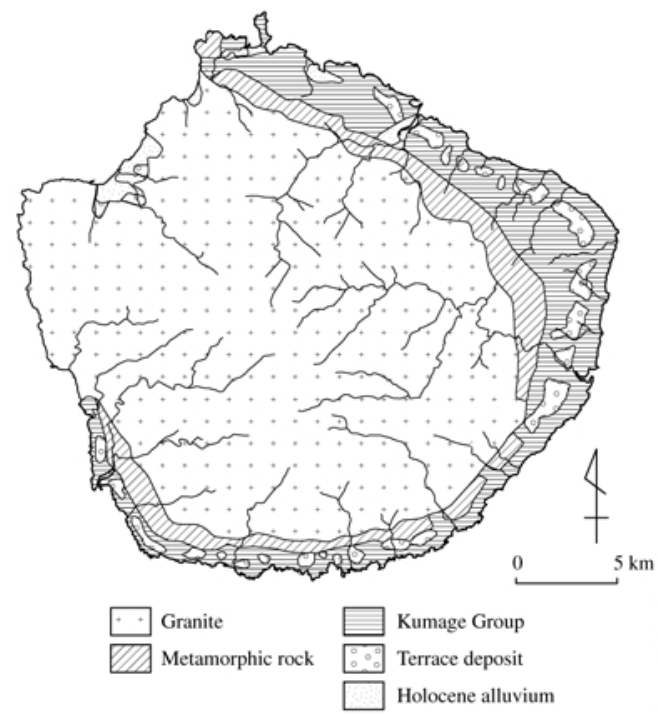

Fig. 2 Geologic map of Yakushima Island (modified after I wamatsu and Ogawauchi, 1984).
山岳部においては年平均気温が $6^{\circ} \mathrm{C}$ 前後と寒冷で ある。宮之浦岳山頂近くでは 2 月に $-10^{\circ} \mathrm{C}$ 以下と なり，3〜 $4 \mathrm{~m}$ の積雪があるといわれる。屋久島 における降水量は多く，小瀬田観測所で年間降水 量 4,359 mm (1971 2000 年の気象庁 AM eDAS データ平均値), 詳細なデータには乏しいが山岳 部では8,000〜10,000 mmに達するといわれる(日 比野，1986; 江口，1984；日下田，2002)。

\section{III. 試料採取と分析方法}

1998年 7月 19 日〜 24日にかけて標高 10〜 1,780 $\mathrm{m}$ の海岸付近から山岳部にわたる 83 地点で湧水・ 沢水・河川水の採水調査を行った (Fig. 1)。本研 究を遂行するにあたり比較的大きな河川では主に 弚の支流で採水を行った。採水前月および当月に 


\section{山 中·奥 村·中 野}

あたる 1998 年 6 月と 7 月には，乥れ午れ 1,047 $\mathrm{mm}, 487 \mathrm{~mm}$ の降水量があり，弚のほとんどは南 方からの季節風によりもたらされたものである (Fig. 3)。また , 小瀬田観測所における 7 月の降 水量としては，15日から 19 日にかけて关れ午れ $101 \mathrm{~mm}, 0.5 \mathrm{~mm}, 29.5 \mathrm{~mm}, 47.5 \mathrm{~mm}, 129 \mathrm{~mm}$ が, 23 日および 24 日には光れ艺れ $21 \mathrm{~mm}$ および $51 \mathrm{~mm}$ か調査最終日 (24日) までに観測されてい る。これら降水量の観測値は低標高域（標高 36 m) におけるものであり，標高のさらに高い地域 ではこれよりも多い降水量であったと予想され る。実際，調査期間中にも降雨が中・高標高域で 存在するにもかかわらず，低標高域では存在しな いという現象か認められた。

採水した水試料は酸素・水素安定同位体組成の 測定を行った。酸素安定同位体組成 $\left({ }^{18} O\right)$ の測 定はEpstain and M ayeda (1953) および千葉ほか (1985) の方法に従って， $\mathrm{CO}_{2}-\mathrm{H}_{2} \mathrm{O}$ 自動平衡法に より質量分析装置 (Finnigan Delta-S) で行った。 水素安定同位体組成( $(\delta$ D) は Coleman et al.(1982) の方法に従って, 金属亜鉛還元法により質量分析 装置 (Finnigan MAT252) で分析を行った。

同位体組成は下式で示すように，標準試料を基

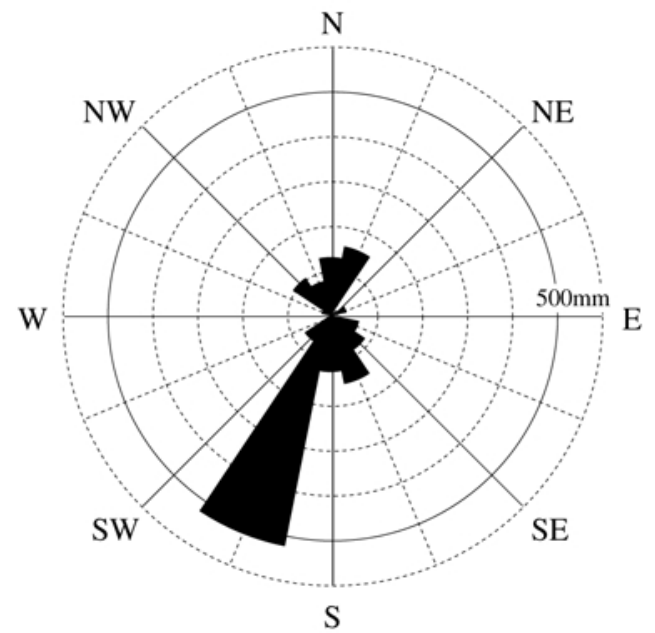

Fig. 3 Rose diagram showing precipitation amounts with wind directions during J une and July 1998 at Koseda, Yaskushima Island (Data are from AM eDAS, JMA).
準とした千分率偏差 $(\%)$ で表示した。

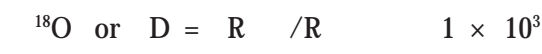

ただし，R は ${ }^{18} \mathrm{O} /{ }^{16} \mathrm{O}$ およびD/H を示し，標準試 料は標準海水 (VSM OW) である。なお, 分析精 度は酸素安定同位体で士 $0.1 \%$, 水素同位体で士 1\%。であった。

\section{IV . 結果および考察}

\section{1. 屋久島河川水における蒸発濃縮の影響}

屋久島河川水の ${ }^{18} \mathrm{O}$ と $\delta$ D の関係をFig. 4 に示

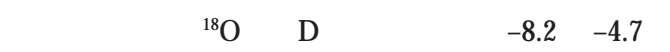
$-54.2 \sim-24.9 \%$ の範囲でばらつきを示した。河川 水の同位体組成は強い相関関係を示し, 兴の線形 近似式 $\left(\delta D=7.68 \delta{ }^{18} O+10.06, R^{2}=0.926\right)$ は 天水線 $\left(\delta D=8 \delta{ }^{18} O+10\right)$ に近いものであつた。 また, 河川水の $\mathrm{d}$ 值 $\left(\mathrm{d}=\delta \mathrm{D}-8 \delta{ }^{18} \mathrm{O}\right.$; Dansgaard， 1964) は $6.5 \sim 16.1 \%$ (平均 : $12.1 \%$ ) であり, 2002 年 3 月の報告值よりも低いものであった (14.6〜 17.2\% ; 林ほか, 2003)。今回得られた $d$ 值は，屋久島における夏季の降水の特徵 $(d=10$, 加藤ほか, 2006) や夏の太平洋気団の特徵 $(d=$ 10 , 早稲田・中井, 1983) に近いものであつた。

このように屋久島河川水が総じて夏季の降水と

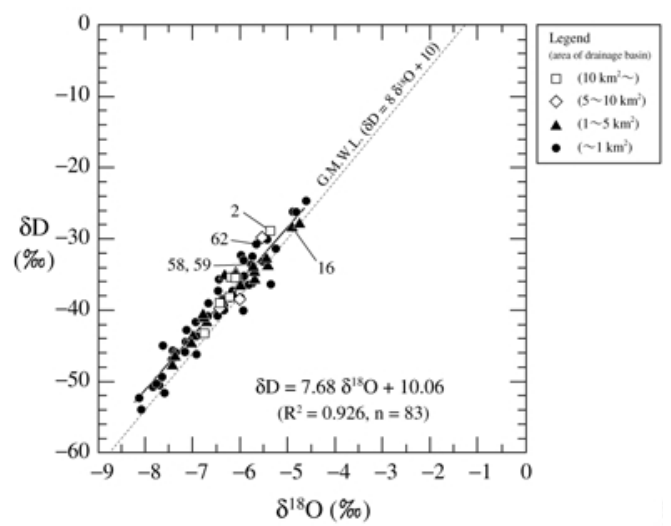

Fig. $4 \delta^{18} O-\delta D$ diagrams for river water in Yakushima Island. Solid and broken lines are regression line for river water samples and Global M eteoric Water Line (G.M.W.L.), respectively. 
似通った同位体的特徵を示すためには, 次の二つ の条件が満たされる必要がある。一つ目として は, 基底流出水の地下における滞留時間が短く， 涵養から流出過程における季節の異なる水体同士 の混合の影響が無視できること。もう一つは, 降 水の表面流出もしくは地下浸透過程での蒸発の影 響が小さいことである。基底流出水については， 屋久島の水理地質的特徵や，河川水の $d$ 值が季節 変動を示す (本研究と林ほか, 2003 との比較) こ とから, 地下での滞留時間は短く, 異なる水体と の混合は無視できると考えられる。二つ目の条件 である蒸発濃縮についても，屋久島河川水か総じ て夏季の降水と似通った同位体的特徵を示すこと から，韦の影響は小さいと予想される。実際に， 蒸発濃縮の影響について正確に把握するために は, 降水との間で同位体組成の比較・検証を行う 必要がある。しかしながら, 屋久島の降水につい ては採取を行っておらず，このような比較・検証 を通じて蒸発濃縮の可能性を否定することはでき ない。乥こで, 同位体組成以外のThornthwaite 法による可能蒸発散量の指標をもとに，この可能 性について検証する。

Thornthwaite法による可能蒸発散量の推定を屋 久島全島域で行うためには, AM eDAS 観測地点 のない高標高域の気温が必要となる。これについ ては屋久島のAM eDAS 観測地点（小瀬田，標高
$36 \mathrm{~m})$ における月別平均気温, および南九州の AM eDAS データから求めた気温低減率 $(-0.627$ ${ }^{\circ} \mathrm{C} / 100 \mathrm{~m}$ ) を使用して Table 1 のように算出した。 採水期間である 7 月の可能蒸発散量は, 気温をも とに標高 $36 \mathrm{~m}, 760 \mathrm{~m}$ および 1,380 m において光 れぞれ $162 \mathrm{~mm}, 112 \mathrm{~mm}, 73 \mathrm{~mm}$ と求められる。 7 月の各地点において可能蒸発散量が降水量に占 める割合 $\left(R_{P E}\right)$ は，光れ光れ $49.8 \%, 12.4 \%$ ， $4.1 \%$ であり, 年平均值で求められる割合よりも高 い。7 月の 3 地点における $\mathrm{R}_{\mathrm{PE}}$ と標高との関係， および近似曲線を Fig. 5 に示す。近似曲線をもと にすれば，RPEが $20 \%$ 以上を占めるのはおよ光標 高 $500 \mathrm{~m}$ 以下の地域であり, 標高 $760 \mathrm{~m}$ および 1,380 m を含めた中·高標高域での RPE はさらに小 さい值となる。この近似式 $h=-554 \ln R_{P E}+2155$ をもとに, 後述する集水域の平均標高 (have) を用 いて 83 の河川流域についてRPE算出した。关の 頻度分布をFig. 6 に示す。一部の流域で $30 \%$ を超 える高い $R_{P E}$ 值も認められるが, 多くの河川流域 ではRPE 值は $10 \%$ 未満である (53 河川)。この中 で最も頻度が高いRPEの範囲は $7.5 〜 10 \%$ であり， $\mathrm{R}_{\mathrm{PE}}$ の平均值としては $10.6 \%$ であった。

Thornthwaite 法をもとに求められた推定量は， 蒸発および蒸散量の総和であるのに対し, 水の同 位体濃縮に影響を及ぼすのは, 蒸発量のみである

(Clark and Fritz, 1997)。このため,Thornthwaite

Table 1 Monthly (July) and annual amounts of precipitation (P), potential evapotranspiration (PE), and P$P E$ at three points in Yakushima Island. Number in parentheses expresses mass ratio of potential evapotranspiration in precipitation ( $\mathrm{R}_{\mathrm{PE}}, \%$ ). The data at Koseda are the average of 1971-2000 (AM eDAS, JM A). The data at Kosugidani (Eguchi, 1984) and Yodogo tozanguchi (Higeta, 2002) are values in 1982 and 1999, respectively.

\begin{tabular}{|c|c|c|c|c|c|c|c|}
\hline \multirow[t]{2}{*}{ M onth } & \multirow[t]{2}{*}{ Point } & \multirow{2}{*}{$\begin{array}{c}\text { Altitude } \\
\text { (h) } \\
(\mathrm{m}) \\
\end{array}$} & \multirow{2}{*}{$\begin{array}{c}\text { Temparature } \\
(\mathrm{T}) \\
\left({ }^{\circ} \mathrm{C}\right)\end{array}$} & \multirow{2}{*}{$\begin{array}{c}\text { Precipitation } \\
\text { (P) } \\
(\mathrm{mm})\end{array}$} & \multicolumn{2}{|c|}{$\begin{array}{c}\text { Potential } \\
\text { Evapotranspiraion (PE) }\end{array}$} & \multirow{2}{*}{$\frac{\text { P-PE }}{(\mathrm{mm})}$} \\
\hline & & & & & $(\mathrm{mm})$ & $(\%)$ & \\
\hline \multirow{3}{*}{ July } & Koseda & 36 & 26.6 & 325 & 162 & $(49.8)$ & 163 \\
\hline & Kosugidani & 760 & $22.3 *$ & 903 & 112 & (12.4) & 791 \\
\hline & Yodogo tozanguchi & 1,380 & $18.2 *$ & 1,812 & 73 & $(4.1)$ & 1,738 \\
\hline \multirow{3}{*}{ Annual } & Koseda & 36 & 19.2 & 4,359 & 967 & $(22.2)$ & 3,391 \\
\hline & Kosugidani & 760 & $14.9 *$ & 7,698 & 609 & (7.9) & 7,087 \\
\hline & Yodogo tozanguchi & 1,380 & $10.8 *$ & 11,426 & 351 & (3.1) & 11,075 \\
\hline
\end{tabular}

*: calculated temperature by using $-0.627^{\circ} \mathrm{C} / 100 \mathrm{~m}$ and temparature of Koseda 


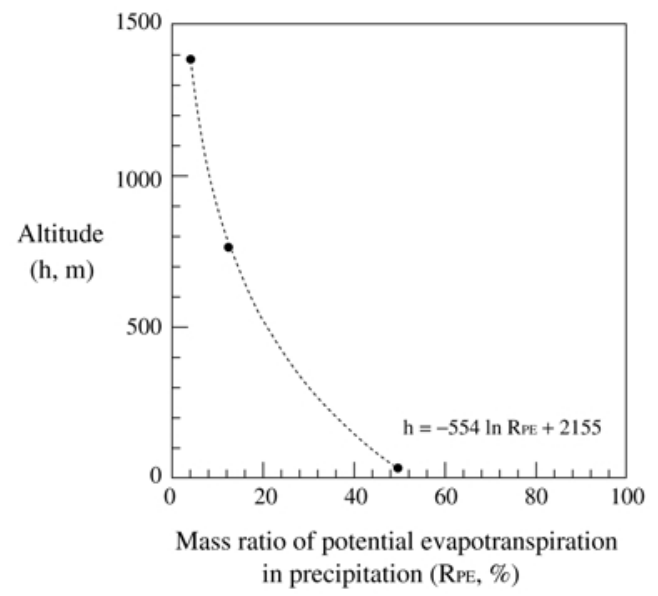

Fig. 5 M ass ratio of potential evapotranspiration in precipitation ( $R_{P E}, \%$ in July against altitude. A broken curve is fitting one for three data plots (Table 1 ).

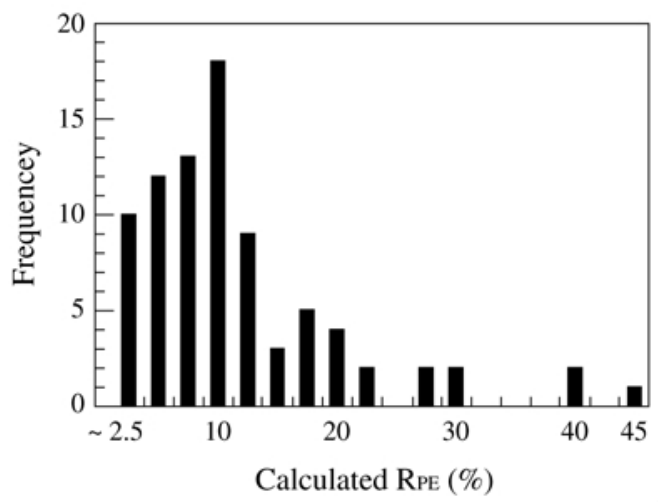

Fig. 6 Histogram of calculated $\mathrm{R}_{\mathrm{PE}}(\%)$ in July on the basis of Equation: $h=-554 \ln R_{P E}+$ 2155.

法をもとに水の同位体濃縮を考えるためには，蒸 発量が降水量に占める割合 (蒸発率, E) を求め る必要があり，同法をもとにした算出值よりもさ らに小さいものとなる。これまでの温帯および亜 寒帯域の森林域についての報告によれば，蒸発散 量に占める蒸発量の割合 $\left(\mathrm{F}_{\mathrm{T}}\right)$ は, 弚のほとんど が 40\%以下である (5\% : Blaken et al., 2001;23\% : 玉井·服部，1994; $24 \sim 28 \%$ : Granier et al., 2000; $24 \sim 35 \%$ : Kelliher and Black, 1986 ; $41 \sim 45 \%$ : Wilson et al., 2001)。ほとんどの標高において森林
が繁茂する屋久島においても，F，は同樣に $40 \%$ 以下であると予想される。光こで，これらの值を 用いて以下のような手順により，蒸発濃縮が屋久 島河川水の同位体組成に与える影響の見積もりを 行った。

蒸発に大きな影響を与える平均気温は, 気温低 減率 $\left(-0.627^{\circ} \mathrm{C} / 100 \mathrm{~m}\right)$ および小瀬田の採水期間 における平均気温 $26.4^{\circ} \mathrm{C}$ (AM eDAS データ) をも とに求めることができる。例えば，集水域の平均 標高 ( $h_{\text {ave }}$ ) の平均值 1,025 m における平均気温は $20.2^{\circ} \mathrm{C}$ と求められる。一方で, 降水が河川水とし て流出するまでにレイリー蒸留過程で一部の降水 か蒸発したとすると， $\delta$ 表記を用いた次のような レイリーモデル式が成立する (F aure, 1986)。

$$
\delta=\left(\delta_{0}+1000\right) f^{(\alpha-1)}-1000
$$

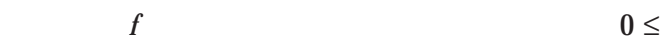
$f \leq 1)$ を $\delta$ およびる。は蒸発を受けた後およびこ れを受ける前の同位体組成を表す。a は水 - 水蒸 気間の同位体分別係数で, M ajoube (1971) により 温度 $(T)$ との間に以下のような関係式が得られ ている。

$$
\begin{aligned}
& 10^{3} \ln { }^{18} O_{\text {water-vapor }}=1.137\left[10^{6} /(T+273)^{2}\right] \\
& -0.4156\left[10^{3} /(T+273)\right]-2.0667
\end{aligned}
$$

$$
\begin{aligned}
& 10^{3} \text { Ina } D_{\text {water-vapor }}=24.844\left[10^{6} /(T+273)^{2}\right] \\
& -76.248\left[10^{3} /(T+273)\right]+52.612
\end{aligned}
$$

これらの関係をもとに,気温 $20.2^{\circ} \mathrm{C}$ のときの同位 体分別係数は, $\mathrm{a}^{18} \mathrm{O}_{\mathrm{w}-\mathrm{v}}=1.00979, \mathrm{a} \mathrm{D}_{\mathrm{w}-\mathrm{v}}=1.08498$ と求められる。また, fについては蒸発率 $E(\%)$ との間に , 次のような関係がある。

$$
f=1-E / 100
$$

$\mathrm{R}_{\mathrm{PE}}$ を平均值の $10.6 \% ， \mathrm{~F}_{\mathrm{T}}$ を $40 \%$ として考えた場 合 , $E=4 \%$ と求められ,さらにこの式から $f=0.96$ と求められる。蒸発後の ${ }^{18} \mathrm{O}$ と $\delta$ 值として, 河川水の平均值である-6.38\%および-38.90\%。用 いた場合には，(2) 式をもとに蒸発濃縮前の同位 体組成は， $\delta{ }^{18} \mathrm{O}_{0}=-6.79 \%$ ， $\delta D_{0}=-42.15 \%$ と求 
められる。ただし ,このときの計算には,$\alpha^{18} \mathrm{O}_{\mathrm{v}-\mathrm{w}}$, a D v-w が用いられることに注意が必要である。こ のときの蒸発濃縮が同位体組成に与える影響 $(\Delta$ $\delta{ }^{18} O$ および $\left.\Delta \delta D\right)$ は, 次式により求められる。

$$
\Delta \delta^{18} \mathrm{O}=\delta^{18} \mathrm{O}-\delta^{18} \mathrm{O} \text { 。 }
$$

$$
\Delta \delta D=\delta D-\delta D_{0}
$$

したがって，この場合には, $\Delta \delta^{18} \mathrm{O}=0.42 \%$, $\Delta \delta \mathrm{D}$ $=3.25 \%$ と求められる。

同樣に , 各流域における $\Delta \delta^{18} \mathrm{O}$ および $\Delta \delta \mathrm{D}$ を 求め, ヒストグラムとして表したものがFig. 7 で ある。なお，このときの $\mathrm{F}_{\mathrm{T}}$ は, 全ての流域で $40 \%$ とした。本研究で採取した屋久島河川水の同位体 組成が蒸発濃縮により受ける影響は, $\delta{ }^{18} 0$ で $0.4 \%$ 以下,$\delta D て ゙ 4 \%$ 以下のものが光のほとんど である。すなわち, 蒸発同位体濃縮の影響は, 大 きく見積もっても分析誤差の 2 倍程度といえる。 この影響は河川水の同位体組成のばらつきに対し

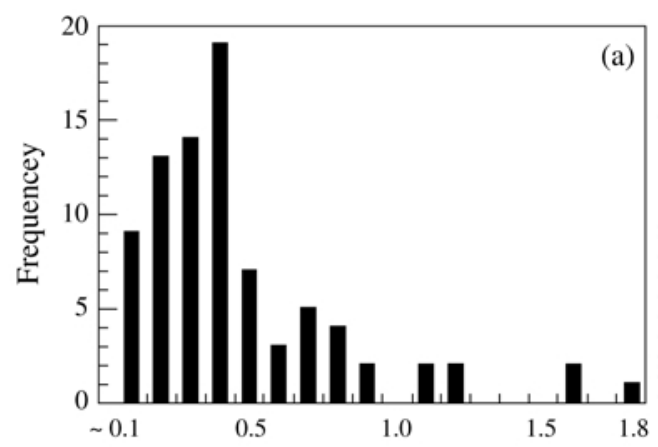

$\Delta \delta^{18} \mathrm{O}(\%)$

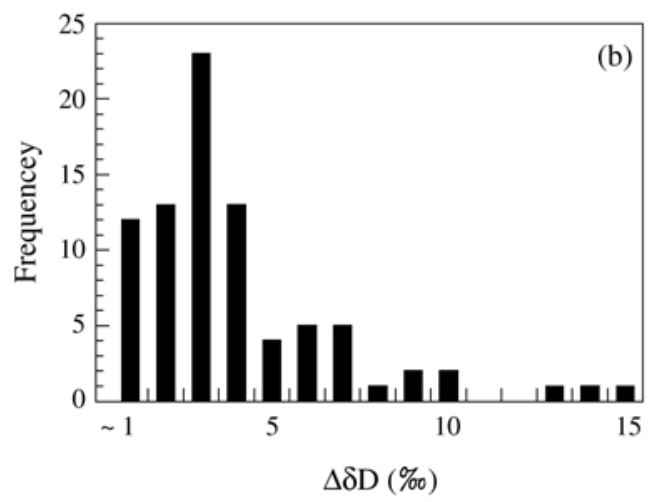

Fig. 7 Histograms of (a) $\Delta \delta^{18} \mathrm{O}$ and (b) $\Delta \delta \mathrm{D}$.
て小さく, 河川水の同位体組成に大きな影響を与 える要因とはならない。このような結果は, 降水 として降り注いだ後に蒸発濃縮の影響をほとんど 受けず, 河川水として流出しているという上述の 考えを支持するものである。

\section{2 . 屋久島河川水の流出特性}

屋久島河川水は, 同位体的特徵や可能蒸発散量 を指標とした検討の結果から，蒸発濃縮による影 響をほとんど受けていないと判断された。一方で， 河川水は蒸発濃縮以外のプロセスによっても, 光 の同位体組成を変化させる。例えば, 異なる季節 の降水に起源を持つような長い滞留時間を持つ地 下水の混入プロセスなどが, これにあたる。この ような地下水の混入プロセスは, 流域規模に大き く規制されるものといえる。流域規模が小さい場 合には, 流域内に保持される地下水量が少ないこ と，屋久島の降水量が極めて多いことを考えあわ せると，これを恒常的に流れる河川水において， 長い滞留時間の地下水が混入する可能性は極めて 低いといえる。これに対して大きな流域では, 保 持される地下水量が相対的に多く，この可能性を 否定できない。光こで流域規模をもとに面積が 1 $\mathrm{km}^{2}$ 未満のものを小規模流域, これ以上のものを 中規模流域として二つに区分し, 以下のような手 順で解析を行った。

降水と同樣の同位体的特徵を持つと考えられる 小規模流域の河川水を対象として, 集水域の平均 標高 ( have) を風早·安原 (1999) および浅井ほか (2001) の方法に従って求め (下記の $(a) 〜(d))$, 产の同位体高度効果を算出した。さらに, 中規模 流域の河川水の同位体組成が，この高度効果のみ から十分に説明できるかどうかを検討すること で, 中規模流域の河川水について滞留時間の長い 地下水が混合している可能性について検証を行っ た。

(a) 標高別降水量 $\left(P_{i}\right)$ を次の近似式により推 定する $\left(P_{i} ; 100 \mathrm{~m}\right.$ 間隔,$h$; 標高 $)$ 。

$$
P_{i}=1.10 h+217
$$




\section{山 中·奥 村·中 野}

なお，近似式に用いた降水量データは Table 1

に示した。

(b) 1/25,000 地形図を用いて各河川水の集水域 の判読を行い, 集水域の面積 (S) と標高 100 $m$ 毎 $\left(h_{i}\right)$ の面積 $\left(S_{i}\right)$ を求める。

（c）各河川水の地形的集水域の平均降水量 $\left(P_{\text {ave }}\right)$ を次式により求める。

$$
P_{\text {ave }}=\sum P_{i} S_{i} / S
$$

(d) 集水域の平均標高 $\left(h_{\text {ave }}\right)$ を次式により求め る。

$$
h_{\text {ave }}=\sum h_{i} P_{i} S_{i} / P_{\text {ave }} S
$$

稜線上で採取した沢水や一部の湧水ついては, 光 の集水域を地形図上で判断することが難しいた め，採水地点標高を代替値とした。これにより求 められた河川水の集水域の平均標高 (have) と同位 体組成 $\left({ }^{18} 0\right.$ およびઠ D) との関係をFig. 8 に示 す。 $h_{\text {ave }}$ と $\delta$ との関係は ${ }^{18} 0$ のものと比較して やや大きなばらつきを示すものの，両者は have の間で強い負の相関関係を示した $\left(\delta^{18} \mathrm{O}: \mathrm{R}^{2}=\right.$ 0.840 ， $\left.\delta \mathrm{D}: \mathrm{R}^{2}=0.741\right)$ 。小規模流域の河川水につ いて得られたర ${ }^{18} 0$ およびठ D の回帰直線の式は， 弚れ光れ以下のようになる。

$$
\delta{ }^{18} \mathrm{O}=-0.00169 \mathrm{~h}_{\text {ave }}-4.64
$$

$$
\delta D=-0.0128 h_{\text {ave }}-25.7
$$

標高 $100 \mathrm{~m}$ あたり高度効果は， $\delta^{18} \mathrm{O}$ およひర D で光れ光れ-0.17\% ，-1.3\% である。これらの值は 中部日本 $\left(\delta{ }^{18} \mathrm{O}:-0.25 \% / 100 \mathrm{~m}, \delta \mathrm{D}:-2.0 \% / 100\right.$ $m$; 早稲田・中井, 1983), 乗鞍 ( $\delta{ }^{18} 0:-0.21 \% 0 / 100$ $\mathrm{m}, \delta \mathrm{D}:-1.5 \% \mathrm{o} / 100 \mathrm{~m}$; 浅井ほか , 2001) といっ た本州における夏季の報告値と比べて小さいもの である。高度効果は中緯度においてర ${ }^{18} 0$ で-0.2 〜-0.4\%o/ $100 \mathrm{~m}$ の值をとり, 弚の值は低緯度ほど 小さいと報告されている(Siegenthaler, 1979)。屋 久島において本州よりも低い高度効果か確認され たことは，この報告と整合するものである。また， 中規模流域も含めた 83 地点の河川水について求 めた高度効果は, $\delta{ }^{18} \mathrm{O}, \delta \mathrm{D}$ ともに先の值と同樣 であった $\left(\delta{ }^{18} \mathrm{O}:-0.173 \% / 100 \mathrm{~m} \delta \mathrm{D}:-1.31 \% / 100\right.$ $\mathrm{m})$ 。なお，一部に回帰直線から大きくはずれてプ ロットされる河川水か認められるが，これについ ては後述する。

地下水成分が河川水の同位体組成に影響を与え ているとすれば, 流域内で保持される地下水量が 多いと考えられる, より大きな流域規模の河川水 において，关の影響は顕著に現れると期待される。 しかしながら，Fig.8の関係において中規模流域 の河川水，特に流域規模が $10 \mathrm{~km}^{2}$ 以上（最大 36 $\left.\mathrm{km}^{2}\right)$ の河川水の多くは, 降水同樣の高度効果を
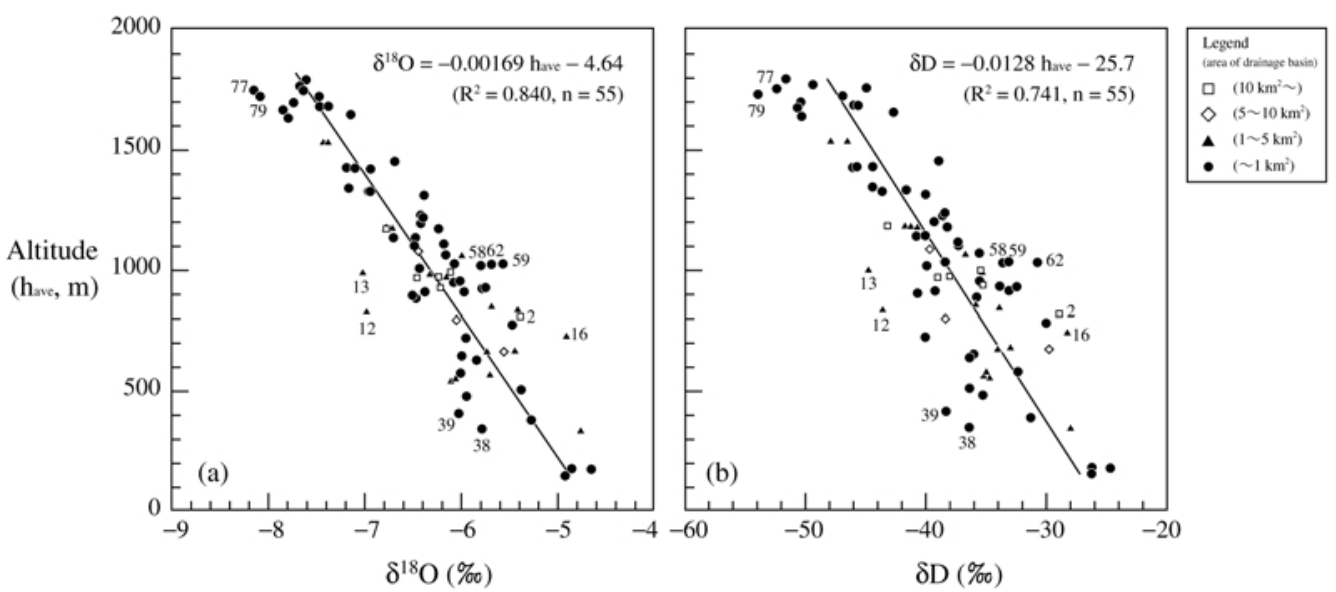

Fig. 8 (a) Plots of ${ }^{18} O$ and (b) $\delta D$ against average altitude of drainage basin in river water. Solid lines express regression lines for the river water whose drainage basin is less than $1 \mathrm{~km}^{2}$ (solid circular symbol). 
持つと考えられる (11) および (12) の回帰直線 付近にプロットされている。このことは，これら 河川水の同位体組成がこの高度効果のみて説明さ れ，長い滞留時間を持つ地下水成分の影響をほと んど受けていないことを示唆するものである。

河川流出に関するこれまでの報告によれば，河 川流出水は降水成分のみならず, 降水とは同位体 組成の異なる地下水成分の影響を強く受けた同位 体組成を持つ。例えば，降雨イベントにおける流 出ピーク時の河川水に占める地下水成分の割合 は，火山岩地域を対象とした浅井ほか (2001) の 報告で 27 ～ $51 \%$ ，主に砂層からなる第四紀堆積物 流域を対象とした Sklash et al. (1976) の報告で は $29 \sim 45 \%$ を占めている。このため，一般的に 河川水は降水とは異なる同位体的特徵を示すもの と期待される。降水の同位体組成を保持したまま 流出するという屋久島河川水の流出特性は, この 島で特徵的に認められる現象といえるであろう。 このような河川水の流出特性は, 極めて多い降水 量および透水性の低い花崗岩基盤といった，屋久 島特有の水文環境に起因するものと考えられ，同 樣の考えを示した海老瀬・永淵 (2002) や永淵ほ か (2002) を支持持するものである。
3 . 採水地点標高から求められる高度効果につい ての検証

河川水の高度効果については一般に平均標高が 使用される一方で, 兴の採水地点標高と同位体組 成の関係に基づいた值も報告されている(早稲田・ 中井，1983; 藪崎ほか, 2003)。このような方法 により高度効果を算出する場合, 前述のように本 来求められるべき高度効果とは大きく異なる值が 導き出される可能性が高い。一方で小規模流域の 河川水のみを扱った場合には, 高度効果について 十分な值が得られる可能性がある。关こで，この 可能性について検証するため, 河川水の採水地点 標高 $\left(h_{\text {sp }}\right)$ と同位体組成 $\left(\delta{ }^{18} 0\right.$ およびठ D) との 関係をFig. 9 に示した。集水域の平均標高 (have を用いた場合と同樣に，小規模流域 $\left(<1 \mathrm{~km}^{2}\right)$ の

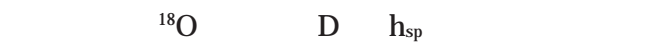
い負の相関関係を示した。採水標高から得られた 同位体高度効果の式は, 以下のように表される。

$$
\delta^{18} \mathrm{O}=-0.00146 \mathrm{~h}_{\text {sp }}-5.01
$$

$$
\delta D=-0.0110 h_{\text {sp }}-28.6
$$

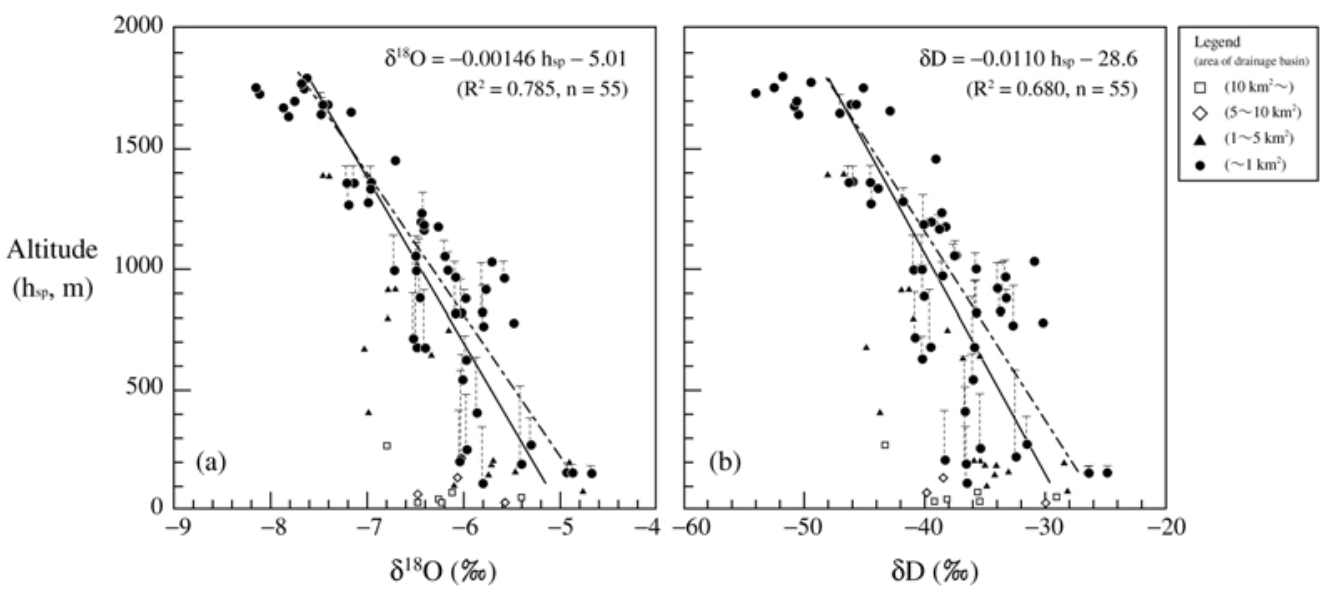

Fig. 9 (a) Plots of $\delta^{18} \mathrm{O}$ and (b) $\delta D$ against altitude of sampling point in river water. Solid lines express regression lines for the river water whose drainage basin is less than $1 \mathrm{~km}^{2}$ (solid circular symbol). Broken lines show altitude effects based on average altitude of drainage basin and are the same lines illustrated as solid ones in Fig. 6. Top of bar charts expresses the average altitude of drainage basin in the river water whose drainage basin is less than $1 \mathrm{~km}^{2}$ (solid circular symbol). 


\section{山 中・奥 村·中 野}

$\mathrm{h}_{\mathrm{sp}}$ から求めた標高 $100 \mathrm{~m}$ あたり高度効果は ${ }^{18} \mathrm{O}$

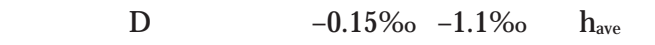
ら求めた值よりも小さいものであった。屋久島の 地形は一般に標高 1,000 1,500 $\mathrm{m}$ までは急激に 高度を増すのに対し, 弚れ以上では比較的なだら かな起伏を持つ。これにともない $1,000 \mathrm{~m}$ 以上の 標高域では $h_{\text {ave }}$ と $h_{\text {sp }}$ の標高にあまり違いが生じ ないのに対し，1,000 $\mathrm{m}$ 以下の標高域ではこの違

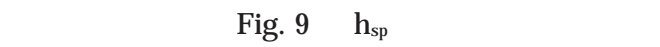
果が本来の值よりも小さく見積もられたのは，こ の屋久島の地形的特徵に起因するものと考えられ る。

このように小規模流域の河川水のみを扱った場 合でも，光の採水地点標高と同位体組成との関係 から求められる高度効果は, 必ずしも十分な値が 得られるとはいえない。また , Fig. 9 において中 規模流域の河川水プロットは高度効果の回帰直線 から大きくはずれており，集水域が大きくなるこ とで高度効果を正確に把握することは, より難し くなる。以上のことから中規模流域の河川水はも とより, $1 \mathrm{~km}^{2}$ 未満の小規模流域における河川水 のみを扱った場合でも，平均標高と採水地点標高 との間で十分な対応が得られない。したがって， 河川水から高度効果を求める上では, 採水地点標 高ではなく，集水域の平均標高を用いる必要があ るといえる。小規模流域の河川が多く存在する屋 久島の河川水において確認されたこの事実は, 一 般的な河川についてもあてはまることと考えられ る。

\section{4 . 降水中の同位体組成分布の推定と光の特性}

前述のように本研究で採水した屋久島河川水の 同位体組成は, 蒸発による同位体濃縮などの影響 をほとんど受けておらず，流域に降り注ぐ降水の 組成を強く反映したものである。したがって，河 川水の同位体組成は, 弚の集水域における平均標 高 ( have $)$ の降水を反映した組成になると考えられ る。さらに，これを屋久島全域の河川水について 適応すれば，屋久島の降水の同位体組成を広域的 に把握できると考えられる。このような考えのも
と, 河川水の ${ }^{18} \mathrm{O}$ 值をもとに, 弚の起源となる 降水の ${ }^{18} 0$ の推定等值線図を描いたものが Fig 10 である。なお，河川水の ${ }^{18} \mathrm{O}$ 值を降水の值と して置き換える際には, 各集水域における $h_{\text {ave }}$ と 一致する標高域のうち，本流上の点を降水の仮想 採取地点とした。また，集水域を地形図上で判断 することが難しい一部の小規模河川水について は, 採水地点を用いた。Fig. 10 における降水の $\delta{ }^{18} \mathrm{O}$ 推定值は，全体的に島中央の高標高域で小さ く，海岸線付近の低標高で大きいという明瞭な同 位体高度効果を示した。このような分布傾向は， 屋久島において河川水の同位体組成から降水の組 成を推定できるという考えが, 空間分布の観点か ら矛盾しないことを意味している。

先に示した have と同位体組成との関係 (Fig. 7) においても，ほとんどの河川水試料は回帰直線付 近にプロットされる形で, 明瞭な同位体高度効果 を示した。この一方で, 河川水試料 2, 12, 13， $16,38,39,58,59,62,77,79$ は回帰直線から 離れてプロットされている。集水域の $h_{\text {ave }}$ とこれ

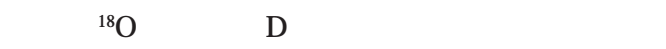
めた標高との差は, 何れも $300 \mathrm{~m}$ 以上であった。

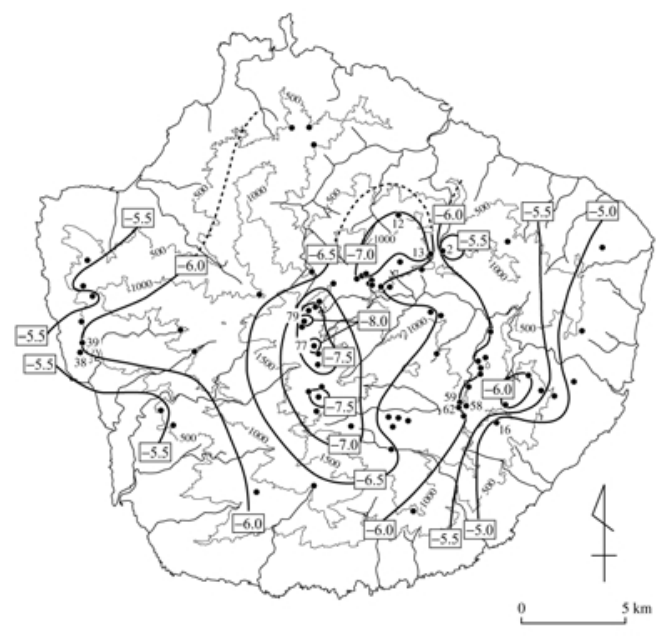

Fig. 10 Estimated spatial distribution of $\delta^{18} \mathrm{O}$ values in precipitation as sources of river water samples. Solid circle symbols express virtual sampling points for precipitation on the bases of average altitude of drainage basin. 
$300 \mathrm{~m}$ という標高差は ${ }^{18} \mathrm{O}$ およびઠ D で 0.5\%お よび $3.8 \%$ という高度効果を生むものであり これ らは上述した蒸発による同位体濃縮の影響よりも 大きなものである。

これら河川水試料から求めた降水の ${ }^{18} 0$ 推定 值は,Fig. 10 において標高と十分な対応を示さな い地域は次の四地域である。島南東部 $(16,58$ 地 点付近), 中央部 $(77,79$ 地点付近), 西部 (38， 39 地点付近) および中央北部 $(12,13$ 地点付近) である。降水の ${ }^{18} \mathrm{O}$ 推定值は, 最初の地域では 標高に対して重い組成を示し，残りの三つの地域 では軽い組成であった。

標高に対して明らかに重い組成をもつ地域は， Fig. 10 の地点 2 を除き, 屋久島南東部に限られる。 同位体組成 (Fig.4) の指標にも，降水から顕著な 蒸発濃縮を受けた傾向は認められないことから， この地域の河川水が局所的に蒸発濃縮の影響を受 けた可能性は低い。この地域において降水の ${ }^{18} \mathrm{O}$ 推定值が局所的に重い組成を持つ要因について は，現時点では不明である。

一方の軽い組成を持つ地域のうち，島中央部は 屋久島で最も標高の高い山岳域である。ここで採 取した試料 77 および 79 につては,Fig. 10 で本 流上の have を持つ地点の代替として採水地点を用 いている。中央部における採取試料が標高に対し て軽い組成を示したのは，採水地点よりも標高が 高い山頂付近に降り注ぐ降水の組成を反映した結 果かも知れない。一方で, 軽い組成を示したほか の二つの地域 (島西部および中央北部) では代替 地点を使用しておらず，同樣の可能性は考えられ ない。一般に，蒸発のような物理的プロセスを通 じて, 水の酸素同位体組成が軽くなることは考え られない。したがって，この要因としては，より 軽い組成を持つ水が混入するか，この地域にもた らされる降水炎のものか軽い組成を持つかの何れ かである。前者としては, 冬季に涵養された同位 体組成の軽い地下水の混入プロセスを挙げること ができるが, この可能性については先に否定した とおりであり これら地域においても例外でない。 一方の後者については, 雨陰効果 (Scholl et al.,
1996; 町田，2000) の可能性を考えることができ る。雨陰効果 (rain shadow) とは, 降水の同位体 組成が卓越風向斜面で重くなり，反対斜面で軽く なる現象である (町田, 2000)。高度効果の回帰直 線をもとにすれば (Fig. 8)，これら試料の供給源 となるべき水蒸気団は, 島北部で標高 1,350 m (地 点 12,13 ), 西部で $800 \mathrm{~m}$ 程度 (地点 38,39 ) の 山稜を越えてもたらされる必要がある。また， 6 月と 7 月の降水は, 主に南方からの季節風により もたらされている (Fig. 3)。実際に, 両地域の南 側にはこれら標高に対応する山稜が存在しており

(Fig. 1 波線部), 南方からの季節風にともなう雨 陰効果が影響を与えるという考えは, 地形的観点 からも矛盾しない。このようなことから，島西部 および中央北部で降水の ${ }^{18} 0$ 推定值が相対的に 軽い組成を示したのは，山稜を超えてもたらされ た降水の雨陰効果による可能性が考えられる。

$$
\text { V . まとめ }
$$

1998 年 7 月に屋久島の標高 $10 \sim 1,780 \mathrm{~m}$ の海岸 付近から山岳部にわたる 83 地点において河川水 試料の採水調査を行い, 酸素および水素安定同位 体組成の測定を行った。兴の結果, 以下のような 知見が得られた。

1 . 河川水の同位体組成は $\delta=7.68 \delta^{18} \mathrm{O}+10.06$ で回帰されるとともに, 弚のd值は $6.5 \sim 16.1 \%$ の範囲でばらつきを示した。これら同位体組成 の特徵から，屋久島河川水は蒸発濃縮の影響を ほとんど受けずに流出していると考えられる。 この考えは可能蒸発散量を指標とした検証の結 果とも整合するものであった。

2 . 降水と同樣の同位体的特徵を持つと考えられ る小規模流域 (1 km² 未満) の河川水を対象と して, 河川水の平均標高と同位体組成との関係 から同位体高度効果の算出を行った。光の結果， 高度効果は, $\delta^{18} \mathrm{O}:-0.17 \% / 100 \mathrm{~m}, \delta \mathrm{D}:-1.3 \%$ / $100 \mathrm{~m}$ と求められた。1 km² より大きい流域を 持つ河川水のほとんどは, 平均標高と同位体組 成との関係において, 小規模流域の河川水から 


\section{山 中·奥 村·中 野}

求められた回帰直線上にプロットされる。この ことから，屋久島河川水の同位体組成は流域規 模にかかわらず高度効果のみから十分に説明さ れ，長期間にわたって流域内で保持された地下 水の混入などの影響は無視できるといえる。こ のような屋久島河川水の流出特性は, 多量の降 水および火山岩に比へ透水性の低い花崗岩流域 といった屋久島特有の水文環境に起因するもの と考えられる。

3. 河川水の平均標高の代替として採水地点標高 を使用し，同位体組成との関係から同位体高度 効果の抽出を試みた。この結果, $1 \mathrm{~km}^{2}$ 未満の 流域の河川水を対象とした場合でも，河川水の 平均標高と同樣の高度効果を得ることはできな かった。このことから，屋久島において河川水 から高度効果を求める上では, 採水地点標高で はなく, 集水域の平均標高を用いる必要がある といえる。

4 . 河川水の組成をもとにした降水の ${ }^{18} \mathrm{O}$ 值の推 定分布図は, 全般的に島中央の高標高域で小さ く，海岸線付近の低標高で大きいという明瞭な 同位体高度効果を示した。一方で，中央北部お よび西部など一部の地域では，標高に対して同 位体組成が明らかに軽い傾向を示すなど，標高 と降水 $\sigma \delta^{18} 0$ 推定分布との十分な対応が得られ なかった。地形および気象条件を考えあわせた 結果, これらの地域で降水の ${ }^{18} 0$ 推定値か軽い 組成を示したのは, 山棱を超えてもたらされた 降水の雨陰効果による可能性が考えられる。

\section{参考文献}

浅井和由, 辻村真貴, 佐竹 洋 (2001) : 乗鞍岳東 斜面における地下水流動系と降雨流出過程, 日 本水文科学会誌, 31, 135-149.

稲村明彦, 安原正也 (2003) : 関東平野と周辺山 地の河川水の水素・酸素同位体比, 日本水文科 学会誌, $33,115-124$.

岩松 暉, 小川内良人 (1984)：屋久島小楊子川 流域の地質, 屋久島原生自然環境保全地域調査
報告書， 27-39.

江口 卓 (1984) : 屋久島の気候 - 特に降水量分 布の地域性について - , 屋久島原生自然環境保 全地域調査報告書, 3-26.

海老瀬潜一・永淵 修 (2002) : 屋久島渓流河川 水質の流出特性と酸性雨影響, 陸水学杂倠誌, 63 , 1-10.

風早康平 (1997): 地下水の涵養と流動: 同位体水 文学的方法, 地質ニュース, 513，20-25.

風早康平, 安原正也 (1994): 湧水の水素同位体 比からみた八ヶ岳の地下水の涵養・流動過程， ハイドロロジー (日本水文科学会誌)，24, 107119.

風早康平, 安原正也 (1999): 岩手火山の地下水流 動系 - 同位体水文学的手法による予察結果 - , 月刊地球, $21,290-295$.

加藤勇治, 浅井和由, 浅井和見, 本島 勳 (2006): 屋久島天然水の水質・同位体特性 (1) - 降水, 河川水 - , 日本地下水学会 2006 年秋季講演会講 演要旨, 38-39.

島野安雄 (1999) : 屋久島の宮之浦岳流水 鹿児島 県の名水，続名水を科学する，203-207.

中村太郎, 佐藤 努, 安原正也 (2002): 御岳南東 斜面における天水の高度効果, 日本水文科学会 誌, 32 , 135-147.

永淵修, 柿本大典, 海老瀬潜一, 浮田正夫 (2002)：渓流河川水質への森林機能の影響, 陸水学杂隹誌, $63,11-19$.

玉井幸治, 服部重明 (1994)：落葉広葉樹林におけ る林床面蒸発のモデル化と流域への適応. 日本 林学会誌, $76,233-241$.

千葉 仁, 酒井 均, 安武正敏 (1985): 水試料の 酸素同位体比の自動測定, 岡山大学温泉研究報 告, $56,27-34$.

林武司, 内田洋平, 石井武政 (2003): 南西諸島 における予察的水文環境研究, 日本水文科学会 誌, 33, 13-18.

日下田紀三 (2002) : 屋久島自然観察ガイド,山と 渓谷, $127 \mathrm{p}$.

日比野雅俊 (1986) : 屋久島の水と水輸出計画, 名 
古屋経済大学市邨学園短期大学人文科学研究会

人文科学論文集，39，105-126.

町田 功 (2000): 東京都三宅島における降水の酸 素安定同位体比時空間変化, 水文・水資源学会 誌, 13，103-113.

水谷義彦,佐竹 洋 (1997)：地下水かん養源の指 標としての河川水の水素および酸素同位体組 成，地下水学会誌，39，287-297.

宮下雄次 (2001) : 酒勾川流域における流域平均 標高と河川水の酸素同位体比との関係 , 神奈川 県温泉地学研究所報告, 32, 7-16.

藪崎志穂, 田瀬則雄, 木方展治, 結田康一 (2003): 茨城県つくば市の水田・畑地・林地における土 壤水および地下水の酸素安定同位体比の特徵, 日本水文科学会誌，33，161-176.

山中 勝, 中野孝教 (2004)：屋久島河川水の水質 および安定同位体組成について,2004 年度日本 水文科学会学術大会発表要旨集, 19，40-41.

山中 勝, 奥村維男, 中野孝教, 島野安雄 (2005): 名水を訪ねて (69), 屋久島の名水, 地下水学会 誌 , $47,253-262$.

早稲田周，中井信之 (1983)：中部日本·東北日本 における天然水の同位体組成, 地球化学, 17,8391.

Blanken P. D., Black, T. A., Neumann, H. H., den Hartog, G., Yang, P. C., Nesic, Z., and Lee, X. (2001): The seasonal water and energy exchange about and within a boreal aspen forest. Journal of Hydrology, 245, 118-136.

Clark, I., and Fritz, P. (1997): Environmental Isotopes in Hydrology. Lewis, N ew York, 328p.

Coleman, M. L., Shepherd, T. J., Durham, J. J., Rouse, J. E., and M oore, G. R. (1982): Reduction of water with zinc for hydrogen isotope analysis. Analytical Chemistry, 54, 993-995.

Dansgaard, W. (1964): Stable isotopes in precipitation. Tellus, 16, 436-468.

Epstein, S., and M ayeda, T. (1953): Variation of ${ }^{18} \mathrm{O}$ content of waters from natural sources. Geochimica et Cosmochimica Acta, 4, 213-244.
Faure, G. (1986): Principles of Isotope Geology, 2nd ed. John Wiley and Sons, New York. 589p.

Granier, A., Biron, P., and Lemoine, D. (2000): Water balance, transpiration and canopy conductance in two beech stands. Agricultural and Forest M eteorology, 100, 291-308.

M ajoube, M . (1971): F ractionnement en exygène18 et en deutérium entre l'eau et sa vapeur. Journal de Chimi Physique et de Physico-chimi biologique, 10, 1423-1436.

Kelliher, F. M., and Black, T. A. (1986): Estimating the effects of understorey removal from a Douglas-fir forest using a two-layer canopy evapotranspiration model. Water Resources Research, 22, 1891-1899.

M azor, E. (1997): Chemical and Isotopic Groundwater Hydrology, The Applied Approach, second ed., $M$ arcel Dekker, New York, 413p.

Nakano, T., Okumura, M., Yamanaka, M., and Satake, K. (2001): Geochemical characteristics of acidified stream water in Yakushima island, a world natural heritage site. Water, Air and Soil Pollution, 130, 869-874.

Scholl, M. A., Ingebritsen, S. E., Janik, C. J., and Kauahikaua, J. P. (1996): Use of precipitation and groundwater isotopes to interpret regional hydrology on a tropical volcanic island: Kilauea volcano area, Hawaii. Water Resources Research, 32, 3525-3537.

Siegenthaler, U. (1979): Stable hydrogen and oxygen isotopes in the water cycle. In: Jäger and Hunziker (Eds.) Lectures in I sotope Geology, Springer, Berlin, 264-273.

Sklash, M. G., Farvolden, R. N., and Fritz, P. (1976): A conceptual model of watershed response to rainfall, developed through the use of oxygen-18 as a natural tracer. Canadian Journal of Earth Sciences, 13, 271-283.

Wilson, K. B., Hanson, P. J., Mulholland, P. J., Baldocchi, D. D., and Wullschleger, S. D. (2001): 


$$
\text { 山 中·奥 村·中 野 }
$$

A comparison of methods for determining forest evapotranspiration and its components: sap-flow, soil water budget, eddy covariance and catchment water balance. Agricultural and Forest M eteorology, 106, 153-168.

Yasuhara, M ., M arui, A., and Kazahaya, K. (1997): Stable isotopic composition of groundwater from M t. Yatsugatake and M t. Fuji, J apan. IAHS publication, 244, 335-344.

(受付 : 2006年 3 月24日)

(受理 : 2007年 1 月31日)

この論文に対する「討論」を2007年11月30日ま で受け付けます。 